\title{
ECO-COSMOPOLITAN STRANGERS: MIGRATION, TOXICITY AND VULNERABILITY IN THE US-MEXICO BORDER THROUGH A REVISION OF LUCHA CORPI'S CACTUS BLOOD
}

\author{
M. ${ }^{a}$ Isabel Pérez Ramos \\ University of Oviedo*
}

\begin{abstract}
Migration flows are common in the US-Mexico border region. However, it has never been so complicated for Latinas/os to cross northwards as it is today. This is due not only to political factors, but also to worsening environmental conditions. Migration, environmental degradation, toxicity and vulnerability are all entangled issues in the US-Mexico border region, as Lucha Corpi's novel Cactus Blood (1995) depicts. When analyzed from an eco-cosmopolitan perspective, the migrant character in the novel, understood as a "stranger"-in the sense of an in-between, insider-outsider character that makes boundaries porous-discloses an environmental awareness that she can use to face her own vulnerability, while at the same time revealing the (global) networks responsible for the environmental degradation and toxicity of certain places, such as the US-Mexico border region. A socio-environmental revision of Cactus Blood-a novel written a quarter of a century ago-highlights issues that are extremely pertinent to confront contemporary challenges.

Keywords: Migration, Eco-Cosmopolitanism, Stranger, US-Mexico Border Region.

EXTRAÑOS ECO-COSMOPOLITAS: MIGRACIÓN, TOXICIDAD Y VULNERABILIDAD
EN LA ZONA FRONTERIZA ENTRE EE. UU. Y MÉXICO A TRAVÉS DE UNA REVISIÓN
DE CACTUS BLOOD, DE LUCHA CORPI
\end{abstract}

\section{RESUMEN}

Los flujos de migración son comunes en la zona fronteriza entre Estados Unidos y México. Sin embargo, para las personas de origen latino cada vez resulta más complicado cruzar la frontera hacia el norte. Esto se debe no solo a factores políticos sino también al empeoramiento de las condiciones medioambientales. La migración, la degradación medioambiental, la toxicidad y la vulnerabilidad son aspectos que están ligados en la zona fronteriza entre EE. UU. y México, como muestra Lucha Corpi en su novela Cactus Blood. De acuerdo con un análisis eco-cosmopolita, la inmigrante de la novela, entendida como una "extrańa" -en el sentido de un personaje que está en medio, dentro y fuera, de modo que hace que los límites se vuelvan porosos- muestra una concienciación medioambiental que le puede servir para enfrentar su propia vulnerabilidad. Dicho análisis sirve a su vez para mostrar las redes (a nivel global) responsables de la degradación medioambiental y la toxicidad de ciertos lugares, como dicha zona fronteriza EE. UU.-México. Una revisión socio-medioambiental de Cactus Blood -escrita ya hace un cuarto de siglo- sirve por tanto para mostrar aspectos que resultan tremendamente pertinentes para afrontar retos contemporáneos.

Palabras Clave: migración, eco-cosmopolitismo, extraña, zona fronteriza EE. UU.-México.

DOI: https://doi.org/10.25145/j.recaesin.2020.81.04

Revista Canaria de Estudios Ingleses, 81; November 2020, pp. 43-59; ISSN: e-2530-8335 
Migrants are themselves nature on the move.

-Marco Armiero and Richard Tucker,

Environmental History of Modern Migrations, 9

Migration, environmental degradation and toxicity, as well as vulnerability, are all entangled factors in the US-Mexico border region. Chicana/o literature often depicts this interrelation through the figure of the migrant and from an eco-cosmopolitan perspective. ${ }^{1}$ The migrant can be understood as an "in-between stranger": "Strangers make social, cultural and physical boundaries porous and unstable; rather than reinforcing boundaries, 'ambivalent people' make them problematic" (Marotta 108). ${ }^{2}$ In this sense, migrants as in-between, insideroutsider characters make boundaries porous, challenge notions of nationality and belonging, as well as environmental understandings and global networks through eco-cosmopolitan attitudes. The eco-cosmopolitanism of some migrants can reflect their environmental awareness-through the way they might use their environmental knowledge(s) to learn from and adapt to their new places of inhabitation, while learning to care for them. This awareness, in turn, might help them face their own vulnerability, itself (partly) derived from their (illegal) migrant/strange status, which might force them to face precarious working and living conditions, often linked to degraded and/or toxic environments. Simultaneously, this awareness exposes the existing (global) networks responsible for migrants'-and other subaltern peoples'vulnerability and overexposure to toxicity and environmental degradation in the border region. Characters such as the border women in Ito Romo's El Puentel The Bridge (2000), the farmworkers from Ana María Viramontes' Under the Feet of Jesus (1995) or the undocumented Carlota Navarro in Lucha Corpi's detective story Cactus Blood (1995) are notable literary examples of these eco-cosmopolitan migrants/strangers. The latter novel is particularly relevant in the context of the eco-cosmopolitan strangers for the significance the plot confers to illegal migration issues as interconnected with toxic environments and socio-environmental concerns.

Corpi has written a set of detective stories that not only criticize racial and economic injustice in the US Southwest, but that revisit key events in the history of

* This research was supported by the Spanish National R\&D Programme, project RTI2018097186-B-I00 (Strangers and cosmopolitans: alternative worlds in contemporary literatures) financed by MCIU/AEI/FEDER, EU, and by the R\&D Programme of the Principado de Asturias, through the Research Group Intersections (grant number GRUPIN IDI/2018/000167). I am also grateful to the Spanish Ministerio de Ciencia, Innovación y Universidades for funding my position as postdoctoral fellow Juan de la Cierva Formación at the University of Oviedo. Finally, I would also like to acknowledge the research group in ecocriticism GIECO-Instituto Franklin, of which I am also a member.

${ }^{1}$ Ursula Heise's concept of eco-cosmopolitanism implies "a sense of planet, a cognitive understanding and affective attachment to the global ... that is, an environmentally oriented cosmopolitanism" (59).

2 For more on the figure of the stranger see Baumann "Strangers"; "Making and Unmaking"; and Simmel "The Quantitative Aspect"; "The Stranger". 
Chicana/o Civil Rights of the 1960s and 1970s. In the case of Cactus Blood, this is the farm workers' strikes against pesticides and for labor rights. The novel-the second in the Gloria Damasco series-starts with the PI-in-training, Gloria Damasco, being hired to investigate a case in Oakland, her hometown, together with her associate and mentor, Justin Escobar. The case is about the presumed suicide of a common friend, Sonny Mares. A video-taped documentary about the United Farm Workers' strike from 1973, some suspicious grapes and two small cuts in the mattress are all the clues they have to start their investigation. Parallel to this, Gloria comes across a recording, an audio tape that was part of the materials for her deceased friend's, Luisa Cortez's, manuscript, "The Chicana Experience, which contained Luisa's interviews of Chicanas who had been involved in the political movement of the sixties and seventies" (30). That tape contains the tragic story of Carlota Navarro, a Mexican orphan who was sold at age fourteen as a domestic to an Anglo-American family living in the San Joaquín Valley, only to end up being raped by the husband of the family, a reputable medical doctor. In her flight from the doctor's household after the rape, she runs "across lettuce and onion fields, passing through vineyards where the sweet but deadly smell of pesticides hung, still fresh, in the air of a hellish dawn" (52). Since she had undergone some deep scrubbing before her escape-"I scrubbed between my legs, around my nipples, and inside my mouth with very hot, sudsy water to wash every trace of Dr. Stephens's sweat, saliva, and semen off my body" (52)-the pesticide, a nerve gas, penetrates deeply into her skin, causing her a toxic trauma that will affect her somatically and psychologically for the rest of her life (Pérez Ramos, "Lands of Entrapment" 136). Carlota's story, therefore, is inevitably linked to that of pesticides-not only because she is physically affected by them, but because she gets involved in the activism against their use, something she has in common with the farmworkers' struggles at the time. This, coincidentally, happens to draw a link with the deceased Sonny Mares, also a Chicano activist involved in the cause against farm workers' exploitation and pesticide (ab)use. Cactus Blood is first and foremost a detective story with a plot which ends up revolving around seemingly unlike issues such as pesticide contamination, toxicity, public health activism, extramarital affairs, guilt and revenge. It has all the necessary elements of the genre: a sleuth, a doubtful suicide and a wide range of suspects to investigate. According to Carol Pearson, "Corpi follows tradition ... regarding the gathering of evidence and the pursuit of clues; the themes of murder, family intrigue, and danger are all present in full measure" (42). Intrigue and suspense are thus guaranteed. Corpi, nonetheless, subverts the genre by integrating some significant changes: she depicts a female Chicana detective with family commitments, with a strong communal sense, a psychic sensibility and a political message, instead of the loner male detective, the hard-boiled white womanizer, who depends solely on rationality to solve the crime and return to the status quo. What one, particularly a reader not familiarized with Chicana/o and/or Corpi's detective fiction, would probably not expect is to find a detective story set in the $90 \mathrm{~s}$ with the Chicana/o struggle for civil rights of the 60s and 70 s in the background and with an environmental dimension that transcends the Chicana/o cause. Due to her subversion of the detective genre and her feminist political commitment, Corpi's work-particularly her Gloria Damasco series-has 
mostly been analyzed from a socio-political and/or feminist perspective so far. ${ }^{3}$ However, the socio-environmental facet has barely been explored, except for the work of Carmen Flys Junquera.

\section{SOCIO-ENVIRONMENTAL ACTIVISM IN CACTUS BLOOD}

Flys Junquera argues that authors such as Corpi subvert the detective genre by adapting it to a Chicana/o ethos of communal values and connection to nature ("Murder"; "Transgressive Appropriations"). The critic stresses how " $t$ ] his [Chicana/o] worldview is clearly involved with community values, the relationship with the land and nature, social justice, and a more intuitive and non-linear way of accessing knowledge" ("Transgressive Appropriations," position 1982). The novel's socioenvironmental dimension thus transcends the most evident references to pesticide toxic poisoning. It adds other layers such as environmental traditional knowledgese.g., curanderismo; water-mindedness in arid, drought-stricken environments; ${ }^{4}$ and a critique of green colonialism/imperialism-through the symbolism of native and alien plant species. She, moreover, questions key border issues, such as illegal migration, and how these issues contribute to the frailty of non-standard Mexican (American) identities, who end up exposed to deficient labor and living conditions and/or to toxic or degraded environments. Corpi, therefore, extends the socio-environmental concerns from the 60s and 70s into the 90s, the time of the novel, concerns that are still unresolved nowadays, when the Covid-19 crisis is an added problem that is increasing even further migrants' vulnerability. Hence, it is through ecocosmopolitanism and the particular "strangeness" of Carlota Navarro that the reader learns about the ongoing unsustainability and socio-environmental injustices that occur in the US-Mexico border. While the social and political commitment of the

${ }^{3}$ Corpi's work has been discussed from the perspective of its political transgression and postcolonial take/revision of empire (Libretti, "Lucha Corpi," "Detecting Empire"); its Chicana feminist transgression of the detective genre (Pearson); its aim to redress history through a review of historical cultural narratives (Steblyk); identity issues such as cultural memory and chicanidad (Rodríguez); Chicana feminist aesthetics and cultural perspectives that contribute to forge a new mestiza consciousness (Maloof); and even through the lens of night, nighttime and darkness as portrayed in the novel in relation to the Mexican (-American) characters (DeGuzmán).

4 Water scarcity in California and its relation to social inequity, is made explicit in the novel mostly by noting water privileges during a drought. For example, when Gloria is visiting an affluent neighborhood in Fresno, "hidden behind tall eucalyptus trees and oaks" with "dark green, freshly-cut turf" and well-watered rose gardens, she claims, "In this Shangrila, people seemed to care nothing about the drought or other people's needs, I realized sadly" (102). See also pages 71 and 189 of the novel. Water scarcity is a key socio-environmental issue in California and the US Southwest. For more on the pressing water issues that affect the US Southwest, and their interrelation to social inequity as portrayed in southwestern literary fiction, see Pérez Ramos "The Water Apocalypse."

5 See Dyer, and Smith and Judd. 
novel is common in Chicana/o detective fiction, the socio-environmental dimension is quite innovative for the genre. Cactus Blood integrates environmental concerns into the plot without making the text revolve exclusively around those issues-a common feature in (Chicana/o) literature with a socio-environmental justice and decolonial take. This narrative technique shows how environmental issues relate to other aspects-social, political, economic, and so on-without necessarily turning the story into a sanctimonious claim for sustainability. It rather presents environmental matters as deeply intertwined with livelihoods and everyday concerns, particularly of the working class and the underprivileged social strata-including undocumented migrants. Corpi's writing has a characteristic activist dimension, being "politically grounded and ideologically radical" (Maloof 99) in line with other detective fiction by Chicanas/os, for "[m]ost Chicano detectives have a worldview that is communal, acutely aware of racism and social injustice, and politically committed" (95). The story displaces "the importance of the individual crime to what she identifies as the larger source of criminality: the social structure itself" (Libretti, "Detecting" 80). Some of the main social issues that surface in Cactus Blood during Gloria's investigation are illegal immigration and human trafficking, male physical abuse (mostly domestic and sexual violence) and farmworkers' labor struggles. All of these aspects, together with the socio-environmental issues, interweave in the narrative, being part of the characters' personal stories and interrelations, and determining their life choices. Among the array of characters, women stand out as particularly sympathetic, pro-active and strong. Carlota Navarro is a central female character. A Mexican illegal immigrant, victim of human trafficking and sexual violence in her adolescence, who also suffers the effects of toxic contamination, Carlota proves to be a resourceful and resilient person through adversity, described as having endless will power and a relentless spirit.

The fact that an undocumented immigrant in California becomes such a relevant character in the plot is not casual. Corpi is herself a Mexican migrantalthough she entered the country legally in the 60 s, as the wife of a Berkeley student. Moreover, the 90 s was a decade full of governmental initiatives intending to hinder illegal migration into the US through its southern border. ${ }^{6}$ Therefore, illegal migrants and migration were a particularly hot topic that decade. In contrast to this attitude, Corpi often mentions the landed aristocracy of Spanish and Mexican descent who

6 "Interest in keeping Mexicans and, more recently, Central Americans from immigrating to the United States resurged in the 1990s. The US Immigration and Naturalization Service (INS) inaugurated Operation Hold-the-Line in 1993, Operation Gatekeeper in 1994, and Operation Safeguard in 1995" (Golash-Boza viii). At state level, in 1994, California Proposition 187, known as the SOS or Save our State initiative and endorsed by the Republican Party, was passed-although it was eventually revoked afterwards (McDonnell). This proposition intended to prohibit undocumented immigrants from receiving services, such as health care and public education. For a news report on 1994 California Proposition 187, see Migration News. For a first-person recollection of the social uprising that came as a reaction to California Proposition 187, see Arellano. The 90s was also quite significant from the Chicana/o activist perspective, due to the death in 1993 of farmworker leader César Chávez. 
had once owned all of California, reminding the dominant US audience of a history long 'forgotten.' The rediscovery and reconstruction of Chicano history and culture, how it was suppressed, together with the increasing awareness of feminist, ecological and social problems, present a different worldview from the dominant Eurocentric one. (Flys Junquera, "Transgressive Appropriations" position 2065-2068). Some of Corpi's main objectives, therefore, are to voice social concerns, fight historical forgetfulness, "increase ecological awareness and incite the reader to action" (Flys Junquera, "Murder" 342). This way "the reader is compelled to reassess his/her position vis-á-vis environmental, social, and political issues. The comfort of apathy and conformism, typical of the genre, is disrupted" (Flys Junquera, "Murder" 353). Corpi promotes that critical attitude through her own protagonist, Gloria, who recognizes that: "I myself have been thinking that I am growing politically apathetic and quite selfish ... And when this is over, I know I have to do a lot of mental and emotional housekeeping" (174). This is a feeling readers could identify with, inciting them indirectly to follow Gloria's example and to stop having a noncommittal, even permissive, attitude-e.g., asking them to practice a responsible and ethical consumption of products such as grapes (Corpi 177-178)-in light of the uncomfortable injustices depicted in the novel, fictional portrayals of current realities that have deep historical roots.

\section{MIGRATION, STRANGENESS AND ECO-COSMOPOLITANISM}

Carlota's migrant character serves to remind the readership that the history of the United States is a story of migration and colonization. She embodies "the history of racial and sexual oppression and labor exploitation ... as an undocumented worker, and 'illegal alien' in her own colonized land" (Libretti, "Detecting Empire" 79). Carlota and the other Chicana/o characters remind the reader that the United States is a country created in the eighteenth century by European migrants, who first claimed and then took over territories all across North America; territories already inhabited by numerous Native American communities, who were decimated and often expelled through coercive tactics from the territory they had traditionally inhabited. Later, in the mid-nineteenth century and after the Mexican American War was over with the signing of the Treaty of Guadalupe Hidalgo (1848), half of Mexico's territory-Mexico being officially a Spanish colony until 1821-became US territory with numerous Mexicans becoming US citizens in their own right. This history is long past, but not forgotten by those whose roots in the North American continent go all the way back to pre-colonial times, such as the Chicana/o community. Moreover, since the annexation of the northern Mexican territories, there have been numerous Mexican (and other Latina/o) citizens, such as Carlota, who have crossed the so-called Tortilla Curtain, migrating (legally or illegally) to the northern neighboring country in order to work. Priscilla Solis Ybarra pinpoints the hegemonic ethnocentric connotations of the historization of migration flows in North America since colonial times in the following terms: 
The Europeans who moved north into Sonora were hailed as conquerors, those who landed on the east coast of North America were revered as pilgrims, and the Europeans who moved West were admired as pioneers. ... Undocumented travelers [nowadays] are labelled 'illegal aliens.' (183)

While the European migrants from colonial times have been "hailed," "revered," and "admired" as "conquerors," "pilgrims" and "pioneers"-concepts traditionally regarded as synonyms for victory, faith and adventure-other migrants, mostly Latinas/os, such as Carlota, are nowadays rather assigned the pejorative label "illegal aliens." "Illegal aliens" are defined as those who live or work in a country other than their country of origin-thus regarded as "alien"-without the legal right to do so. According to this definition, the "conquerors," "pilgrims" and "pioneers" who travelled to North America could all be regarded as illegal aliens, but that concept did not apply at the time and history has rather depicted them in much more positive and heroic positions: as audacious men-for women were mostly depicted as passive, if not invisible, characters in these narratives- men who risked and/or sacrificed their lives in the name of Christianity and civilization. Naming and labelling, of course, have a lot to do with who tells the story.

What can be inferred from US southwestern history is that the connection between the US and Mexico has always gone beyond their geographical proximity, in the form of (legal as well as illegal) human flows moving constantly and bidirectionally across the border-wherever this was located. A border that, since its inception, has gone from being something mostly conceptual (a political division) to being something solid and physical: a fence or a dreaded wall. Despite the different measures taken by the US government to keep immigrants from crossing its southern border, people have kept migrating north, which has led to an increase in the number of deportations. Focusing on the massive deportation of Latino men from the United States, Tanya Maria Golash-Boza argues that the systematic deportation that has been increasing in numbers since the 90 s is part of what she terms "the neoliberal cycle": a system of labor and political reforms that follow neoliberal economic principles.7 Building on her neoliberal-cycle theory, GolashBoza comments on the existing contradiction that promotes labor migration, "opening borders for capital," while offering few options for legal migration (16). Monica Varsanyi calls this contradictory pattern the "neoliberal paradox" (879). This paradox forces most Latina/o migrants, such as Carlota, in search of better living conditions than those they can afford in their native countries, to risk their lives to enter into the country illegally in order to access the kind of jobs available to them-mostly non-skilled service jobs. Golash-Boza claims that the neoliberal cycle is behind what Joseph Nevins and Mizue Aizeki term global apartheid, "a system where mostly white and affluent citizens of the world are free to travel to where they

7 This cycle is constituted by elements such as inequality and outsourcing, low-wage works resulting from economic restructuring, cutbacks in social services, the enhancement of police, the military and immigration enforcement, and privatization of public services (Golash-Boza 2-3). 
like whereas the poor are forced to make do in places where there are less resources" (Golash-Boza 3). This term in turn relates to the concept of eco-apartheids, "(urban) environments [at local, regional, or even national level] in which the wealthy and the privileged inhabit shelters or sheltered areas to escape pollution, toxicity, and the effects of climate change, while the underprivileged are endangered in the remaining degraded and exposed areas" (Pérez Ramos, "Toward" forthcoming). ${ }^{8}$ In the case of the US-Mexico border region, multinational trade agreements, such as NAFTA, have greatly contributed to foster eco-apartheids, sending not only manufacturing industries to the southern side of the border, but also their waste products (Pérez Ramos, "Lands of Entrapment" 137-141).?

What the concept of eco-apartheid discloses is that, other than social, racial and economic factors, there are environmental causes behind patterns of migration, segregation and discrimination. Environmental factors are often key to explain the flows of human beings across the globe. ${ }^{10}$ Environmental degradation and/or resource scarcity can be key causes that help explain migration patterns. Nowadays, climate change-due to its particularly adverse effects on certain parts of the planetis becoming another important migration factor (Climate). One should also keep in mind that, "[w]ars and poverty, two crucial causes of migration, can also be explained as consequences of environmental-more specifically climate-changes" (Armiero and Tucker 2; "Climate Change"). In the case of northward migration through the US-Mexico border, there are mainly two environmental problems that might foster it: (toxic) pollution and water scarcity issues. ${ }^{11}$ Moreover, migration has an important socio-environmental impact on the migrants that has to be acknowledged. As Marco Armiero and Richard Tucker put it:

The experience of migration often left indelible traces in the bodies of those who were exposed to unfamiliar threats and hazards.... [I]f planting grapes, harvesting the sea, mining coal, or simply surviving in the tenements of the metropolis, had

${ }^{8}$ For more on the concept of eco-apartheid, see also Pérez Ramos, "Water Apocalypse"; Ross 17, 70-71, 239-240, 250.

9 NAFTA stands for North American Free Trade Agreement (1994-2020). In 2018, a new trade agreement was signed by the United States, Mexico and Canada to replace NAFTA: The United States-Mexico-Canada Agreement (USMCA). USMCA came into force on July 1, 2020. This new agreement supposedly increases environmental and working regulations, although NAFTA also contemplated some environmental provisions that were not followed eventually (Pérez-Ramos, "Lands of Entrapment" 137).

${ }^{10}$ Some classical texts that investigate the socio-environmental factors and/or consequences of migrations are Alfred Crosby's The Columbian Exchange (1972) and Ecological Imperialism (1986); Richard Grove's Green Imperialism (1995); Jared Diamond's Guns, Germs, and Steel (1997); and Thomas Dunlap's Nature and the English Diaspora (1999). See also Marco Armiero and Richard Tucker's Environmental History of Modern Migrations (2017).

${ }^{11}$ For an analysis of how Chicana/o literature has addressed the toxic pollution of the US-Mexico border, see Pérez Ramos "Lands of Entrapment." For information on how climate change is affecting Mexico, increasing water scarcity in the country, see "Comments" and "How." 
a 'natural' substance, then migrants do indeed have their environmental stories waiting to be told. (5)

The way migrants interact with the new environments can affect them both physically and mentally. This is certainly the case of Carlota, whose body and mind are living witnesses of all she has endured as a migrant: a rape survivor who could not go to the police due to her illegal status; who suffers from speech disorder, a failing memory and emotional instability, mostly as a consequence of her pesticide intoxication during her escape, and her inability to access the healthcare system; a person who suffers from an unspecified fatal condition that will take her life soon. As argued in the introduction, migrants can themselves be regarded as in-between strangers, as uncomfortable characters who question the status quo. Carlota is certainly proof of this. On the one hand, she is an all-too-clear, disturbing example of the consequences of the fluctuation of (toxic) matter in the environment and atmosphere, and the inevitable interrelation of toxicity with bodily natures, what Stacy Alaimo terms "trans-corporeality." Carlota's brain damage shows the terrible effects of toxic chemicals in a porous, living organism (as it has been so often the case with farmworkers). Through her accidental exposure to pesticides, she becomes an uncomfortable proof of the "human price to be paid for the unblemished apple or grape.... The proverbial poisoned apple" (Corpi 114). Her neurological disorders, moreover, represent the general condition of the Chicana/o and the Mexican migrant communities in the US:

In her capacity to represent the violence enacted on farmworkers bodies, Carlota becomes a metonym for the Chicana/o body politic. She is a frightening representative because the neurological damage she suffered affects both her speech and her memory. Her failing voice speaks to the agency often denied marginalized communities, but it is her failing memory that truly haunts Gloria. The chemicals rotting her memory are not unlike the canon of history denying voice and identity to Chicanas/os. (Rodríguez 67-68)

Carlota embodies the consequences of the invisibility of the Chicana/o community in the US-a community of ten exposed to toxic pesticides, something particularly problematic in the case of undocumented workers due to their impossibility to access proper health care-while she constantly challenges her invisibility through her perseverance and activism. Her illegal status and the derived inaccessibility to proper health care, moreover, introduce the aspect of curandería and shamanism as alternative environmental knowledges; "curandería (folk medicine) ... expresses a worldview anchored in spiritual awareness and a connection to the natural environment" (Lomelí et al. 302). Various characters in the novel try to help Carlota with these means after she is poisoned, but to no avail. Contrary to what it might seem, the novel does not present this as proof of the inefficiency of these traditional knowledges, which are "still very much a part of [Chicana/o] culture" (Lomelí et al. 302). The novel rather seems to claim that traditional, natural remedies are not enough to treat patients who have been overexposed to laboratory-designed toxic substances. Carlota's body, therefore, serves as a bridge between cultures 
and knowledges, being treated by several different healing traditions that in the story appear as equally valid, necessary and complementary. Eco-cosmopolitanism and critical cosmopolitanism are particularly relevant concepts when considering how migrants' own environmental awareness and knowledge can help them in their adaptation to new environments and challenges. Critical cosmopolitanism, according to Walter Mignolo, consists in a re-conception of cosmopolitanism from the perspective of coloniality-key in a transnational world (723-724). Two necessary conditions for critical cosmopolitanism are "[b]order thinking or border epistemology-... the recognition and transformation of the hegemonic imaginary from the perspectives of people in subaltern positions," and diversality or "diversity as a universal and cosmopolitan project in which everyone participates instead of 'being participated"' (736-737; 744). The character of Carlota Navarro certainly partakes of these conditions, both literally-from her subaltern position as an illegal border migrant-and figuratively-as a stranger who proactively transgresses political, cultural and social borders through her socio-environmental awareness and commitment as an activist. On the other hand, Ursula Heise presents ecocosmopolitanism as a way to address the current global socio-environmental challenges we are facing, without losing perspective of the different varieties of environmentalism and the value of situated knowledges. It is, moreover-and in contrast to other theories on cosmopolitanism-inclusive of the more-than-human world, that is of communities formed both by humans and by more-than-human animate and inanimate nature (Heise 60-61). Heise's eco-cosmopolitan theory aims to unveil the political frameworks that sustain communities, as well as make salient connections among peoples and environments, something that is also essential in migration narratives (62).

Carlota, as someone who confronts pesticide poisoning, practices ecocosmopolitanism-albeit inadvertently-for "[a]lthough trans-corporeality as the transit between body and environment is exceedingly local, tracing a toxic substance from production to consumption often reveals global networks of social injustice, lax regulations, and environmental degradation" (Alaimo 15). Carlota's ailments problematize pesticide production because of the interconnections it bears with abuse, migration, labor exploitation and environmental degradation. Her predicament reveals the international consequences of the "neoliberal cycle" theorized by Goulash-Boza, where someone who lives and works in a country, having survived human trafficking, labor exploitation, sexual abuse and pesticide poisoning, cannot resort to the government for assistance. Moreover, Carlota, in contrast to traditional characters in Chicana/o literature, who practice a deep sense of place and of belonging to a particular locale, is an uprooted character. She is an orphan who left her homeland at age fourteen with the promise of a better life in the US, who twenty-years later still remains an illegal immigrant, always on the run, until, upon learning that she is fatally ill, she decides to return to her homeland to die. Nevertheless, this does not mean that she does not have an environmental awareness. Proof of this is that she does not travel alone. To her emotional luggage, consisting of memories of her life in Mexico, as well as her memories and knowledge of the place(s) and environments she has known and left behind, Carlota adds a 
travel companion, a prickly pear cactus: ${ }^{2}$ "A few clothes and my family photos in a Mexican burlap shopping bag, together with that tiny, one-leaf, Mexican cactus Chuchita [a friend] and her mother gave me the night before I left were my only possessions" (45). Since the day she left her native village, she carries a prickly pear cactus everywhere with her. The relevance of cacti in the plot is quite clear from the title of the novel: Cactus Blood. Although cacti might seem to relate exclusively to Gloria's vision at the very beginning, a vision that predicts the denouement of the story, the relevance and symbolism of this plant goes well beyond that. Carlota's nopalito is "a symbol of her land, her relationship to the earth" (Flys Junquera, "Murder" 353); it also represents Carlota's own spirit: resilient, adaptive and tough. Carlota is also referred to as "flor/florecita de nopal" by her friend Ramón Caballos (216-217), and the nickname is certainly quite appropriate since, as Carlota relates, her own life parallels the cycle of the nopal flower: ${ }^{13}$

'Dicen que florea una flor azul, casi morada,' I remembered Chuchita telling me as she explained that the cactus flower was a violet blue, that it bloomed in cycles of five years. My grandmother, the only grandparent I knew, died when I was three years old. Just before her death, she consulted the stars and the corn kernels on my behalf. She predicted that my life would evolve in cycles of five years, that I would shed many tears, but that, finally, on the seventh cycle I would find happiness. (45-46)

Indeed, Carlota's life does change significantly every five years. For example, the day before turning fifteen she is raped, and she is likely to die at the age thirtyfive, "on the seventh cycle"- but not before returning to her beloved homeland with a good friend, who cares deeply for her, leaving behind a life of suffering. A nopal, moreover, is always by her side at the most difficult times, like when she is suffocating in Dr. Stephens' car trunk while crossing the border and the nopal pricks her to remind her that she is still alive (46). Again, after being raped and before leaving the Stephens' house, she digs her cactus up from the place where she had planted it and takes it away with her. A few drops of her blood symbolically drip over the cactus' stem, bringing to mind once again the book's title, with her blood denoting her physical and emotional suffering, as well as her uprootedness from yet another home. The cactus also serves to call attention upon the concept of "alien," often used to refer not only to immigrants, but also to introduced plant species. When departing from the Stephens' house, and in order to take her cactus with her, Carlota leaves behind a crushed gardenia in a very symbolic gesture:

I planted it [the cactus] into a pot from which, a moment ago, I'd yanked out a favorite gardenia that Dr. Stephens intended to transplant ... I tore out the blossoms

12 Prickly pears, also known by the Nahuatl term nopales, are native to the Americas with numerous varieties native to the arid and semi-arid regions of northern Mexico and the US Southwest (including California, where the action of the novel takes place).

${ }_{13}$ Notice that "nopal" is also a cultural symbol to indicate origins and connection to roots and identity. 
and mashed them with my foot until the sweet aroma of the fresh blossoms turned into a sickening stench of crushed flowers. (52)

Gardenias are native to China and they require abundant humidity to live, therefore being quite alien to and unfitting for the US Southwestern climate, unlike Carlota's nopal. Moreover, in China they are symbols of "feminine grace; subtlety" (Cooper 375). Carlota, the survivor of a rape, rebels against the exotic flower, unfit for that place and climate, crushes it as her abuser crushed her-perverting her blossoming femininity. Cacti also represent Carlota's trace in the lives of her close friends, who all have a series of nopales planted in their yards, plants that symbolize the roots she has put down in that land, and the reciprocal positive impact between those people/land and her (unlike the Stephens' house from where she dug up her cactus). Before leaving for Mexico, Carlota gives her last nopal to Gloria, who aims to honor Carlota's memory by planting it in a place with a particular personal significance: “'Tomorrow, or when this is over, I will plant the tiny nopal at the foot of Luisa's grave,' I promised aloud, looking up at the morning star punctuating the canvas of the night" (250). Ralph E. Rodríguez goes as far as to regard "the Chicana/o community as metonymically represented by the cactus," with nature serving "as a beneficent marker of memory" (69); memories of human flows, of sorrow, suffering and survival, of friendship and kinship.

Interestingly enough, throughout the book, Carlota is not only identified with prickly pear cacti, but also with an "alien" plant species, weeping willows. ${ }^{14}$ Weeping willows are part of her happy childhood memories:

I remembered the weeping willows, bordering the river and dancing in the moonlight like gigantic grass skirts. My friend Chuchita and I used to help our mothers do the wash at the Media Luna, then bathe and play in the cool water before we went back to our school. (44-45)

The specific plant species is also present at her friends' yards: "If this weeping willow wasn't here before, Josie [Carlota's friend] surely planted it for Carlota"' (71); "There, in the front yard [of her friend Maria Baldomar], ... stood a weeping willow next to a prickly-pear cactus-green sentinels guarding Carlota Navarro's memories of her village in Mexico, lifetimes ago" (79). Although weeping willows can be seen as symbols of mourning (Cooper 1028), they are also well known for their endurance and "strength in weakness," surviving storms and strong winds by bending instead of resisting (1029). Weeping willows, thus, represent quite well Carlota's endurance through her tough life-orphan, migrant, (illegal) alien, undocumented worker, rape survivor, pesticide-poisoned person. Therefore, both prickly pears and weeping willows-one native to the arid biosphere of northern Mexico and Southwestern US, one not-are symbols of Carlota's eco-cosmopolitanism, proof of her environmental

14 Weeping willows, native to Asia, are nowadays present all over the world, particularly in arid regions, near rivers and water courses, used mainly to give shade and provide erosion control. 
awareness as well as of her strength, endurance and adaptability. At the same time, the symbolic uses of these two plant species, as well as of gardenias, serve to question green colonialism/imperialism discourses by questioning the concept of "alien," common in those discourses as well as in the context of human migrations.

\section{CONCLUSION: ECO-COSMOPOLITAN STRANGERS FOR CHANGE}

With its claims for socio-environmental justice, Cactus Blood is not the typical detective story. It presents a clear and unusual political stance against labor exploitation, pesticide poisoning and male physical abuse, and voices a claim for migrants' and women's' rights. In the process, Corpi highlights the "strangeness" of (illegal) migrants, as people that challenge the status quo and established notions of what is fair and just, people that question existing laws and regulations, becoming living proofs of uncomfortable truths, such as the high and cruel price to pay for something as capricious as the consumption of flawless fruits and vegetables, or as unsustainable as the intensive agricultural system. In the particular case of this novel, this challenge goes hand in hand with the migrants' (in this case Carlota's) eco-cosmopolitanism, as a key resource to counter and expose the vulnerability of subaltern beings in the fragile-often toxic and degraded-environment of the US-Mexico border.

Judi Maloof concludes her analysis of Corpi's detective Gloria Damasco series stating that, "Damasco also has an extraordinary ability to see how the past is linked to the future, and how the Chicano Civil Rights Movement of the 1960s and 1970s is linked to current struggles for racial equality and social justice" (111). Unfortunately, this is still true nowadays, a quarter of a century after the publication of Cactus Blood. Golash-Boza's work shows how the situation for Latina/o migrants, such as Carlota, willing to go to the US to access jobs that need labor-as well as for those that are already in the country working, albeit illegally-keeps getting worse. This, in turn, keeps increasing their vulnerability, which is further affected by other factors, as in the current times of global pandemics, when migrants are not requesting medical attention for fear of being deported or of being denied the right to citizenship. ${ }^{15}$ Books such as Corpi's Cactus Blood keep reminding readers fifty years later, when old challenges have yet to be overcome and new threats and difficulties keep arising, that a change is necessary. The eco-cosmopolitan stance of the novel proves that this change cannot only be local or community-based, but that it has to address the economic system, as well as social and environmental policies at national and transnational level. It is time to honor Corpi's subversion of the detective genre with her personal style and political message, by working actively in order to foster eco-cosmopolitan attitudes to tackle old and contemporary challenges,

15 See Dyer. 
by disturbing the status quo and by reacting to longstanding and pervasive (socioenvironmental) injustices in the border region and beyond.

REVIEWS SENT TO AUTHOR: 23-5-2020; REVISED PAPER ACCEPTED FOR PUBLICATION: 5-8-2020 


\section{WORKS CITED}

Alaimo, Stacy. Bodily Natures: Science, Environment and the Material Self. Indiana UP, 2010.

Arellano, Gustavo. "Prop. 187 Forced a Generation to Put Fear Aside and Fight. It Transformed California, and Me.” Los Angeles Times, 29 Oct. 2019. https://www.latimes.com/california/ story/2019-10-29/proposition-187-california-pete-wilson-essay.

Armiero, Marco, and Richard Tucker. Environmental History of Modern Migrations. Taylor \& Francis, 2017.

Bauman, Zygmunt. "Making and Unmaking of Strangers." Thesis Eleven 43 (1995): 1-16.

Bauman, Zygmunt. "Strangers: The Social Construction of Universality and Particularity." Telos 78 (1988-1989): 7-42.

Climate and Migration Coalition. Climate Outreach, http://climatemigration.org.uk/. "Climate Change, Armed Violence and Conflict." Climate and Migration Coalition. Climate Outreach, http://climatemigration.org.uk/climate-change-armed-violence-and-conflict/.

"Comments on Mexico and Climate Change and Security." United Nations, http://sustainabledevelopment. un.org/content/dsd/resources/res_pdfs/ga-64/cc-inputs/Mexico_CCIS.pdf.

Cooper, J.C. An Illustrated Encyclopaedia of Traditional Symbols. 1978. Thames \& Hudson, 2012. Apple Books Edition.

Corpi, Lucha. Cactus Blood. 1995. Arte Público Press, 2009. Kindle Edition.

Crosby, Alfred. The Columbian Exchange: Biological and Cultural Consequences of 1492. Greenwood Press, 1972.

Crosby, Alfred. Ecological Imperialism: The Biological Expansion of Europe, 900-1900. Cambridge UP, 1986.

Deguzmán, María. Buenas Noches, American Culture: Latinalo Aesthetics of Night. Indiana UP, 2012. 56-61.

Diamond, Jared. Guns, Germs, and Steel: The Fates of Human Societies. W.W. Norton \& Company, 1999.

Dunlap, Thomas. Nature and the English Diaspora: Environment and History in the United States, Canada, Australia, and New Zealand. Cambridge UP, 1999.

Dyer, Owen. "Covid-19: Black people and other minorities are hardest hit in US.” British Medical Journal. 369 (14 April 2020) doi: 10.1136/bmj.m1483.

Flys Junquera, Carmen. "Murder with an Ecological Message: Rudolfo Anaya and Lucha Corpi’s Detective Fiction." Revista Canaria de Estudios Ingleses 42 (2001): 341-357.

Flys Junquera, Carmen. “Transgressive Appropriations in Lucha Corpi’s Detective Fiction.” Borderline Identities in Chicano Culture, ed. Michele Bottalico \& Salah el Moncef bin Khalifa, Soglie Americane Book 2 Mazzanti Editori, 2006. 115-131. Kindle Edition.

Golash-Boza, Tanya Maria. Deported: Immigrant Policing, Disposable Labor, and Global Capitalism. New York UP, 2015.

Grove, Richard H. Green Imperialism: Colonial Expansion, Tropical Island Edens and the Origins of Environmentalism 1600-1860. Cambridge UP, 1995.

Heise, Ursula. Sense of Place and Sense of Planet: The Environmental Imagination of the Global. Oxford UP, 2008. 
"How is Climate Change Affecting Mexico." The Climate Reality Project, 2018. Climate Reality Leadership Corps, https://www.climaterealityproject.org/blog/how-climate-changeaffecting-mexico.

Libretti, Tim. "Detecting Empire from Inside-Out and Outside-In: The Politics of Detection in the Fiction of Elizabeth George and Lucha Corpi." Race and Religion in the Postcolonial British Detective Story, ed. Julie H. Kim, McFarland, 2005. 71-95.

Libretti, Tim. "Lucha Corpi and the Politics of Detective Fiction." Multicultural Detective Fiction: Murder from the Other Side, ed. Johnson Gosselin, Garland Publishing Inc., 1999. 61-82.

Lomelí, Francisco A., et al. "Trends and Themes in Chicana/o Writings in Postmodern Times." Chicano Renaissance: Contemporary Cultural Trends, ed. David R. Maciel, Isidro D. Ortiz \& María Herrera-Sobek, U of Arizona P, 2000. 285-312.

Maloof, Judy. "The Chicana Detective as Clairvoyant in Lucha Corpi's Eulogy for a Brown Angel (1992), Cactus Blood (1996), and Black Widow's Wardrobe (1999).” Ciberletras: Journal of Literary Criticism and Culture 15 (2006): 92-113. http://www.lehman.cuny.edu/ciberletras/ documents/ISSUE15.pdf\#page=92.

Marotta, Vince P. “The Cosmopolitan Stranger.” Questioning Cosmopolitanism, ed. Stan van Hooft \& Wim Vandekerckhove, Springer, 2010. 105-120. doi: 10.1007/978-90-481-8704-1_7.

McDonnell, Patrick J. “Davis Won't Appeal Prop. 187 Ruling, Ending Court Battles.” Los Angeles Times, 29 July 1999, https://www.latimes.com/archives/la-xpm-1999-jul-29-mn-60700story.html. Accessed 27 June 2020.

Mignolo, Walter D. "The Many Faces of Cosmo-polis: Border Thinking and Critical Cosmopolitanism.” Public Culture 12/3 (2000): 721-748. doi: 10.1215/08992363-12-3-721.

Migration News. “'Save Our State' Initiative Qualifies.” U of California, Davis, https://migration. ucdavis.edu/mn/more.php?id=386.

Nevins, Joseph, and Mizue Aizeki. Dying to Live: A Story of US Immigration in an Age of Global Apartheid. City Lights, 2008.

Pearson, Carol. "Writing from the Outside In: Constructs of Memory and Chicanas as Private Eyes in Three Detective Novels by Lucha Corpi." Interdisciplinary Literary Studies: A Journal of Criticism and Theory 4/1 (Fall 2002): 38-51.

PÉrez Ramos, M. ${ }^{a}$ Isabel. "Lands of Entrapment: Environmental Health and wellbeing in literature about the US Southwest and Chicano Communities." MELUS: Multi-Ethnic Literature of the United States 43/2 (June 2018): 129-150. doi: 10.1093/melus/mly010.

Pérez Ramos, M. a Isabel. "Toward an Eco-Social Transition: From the Age of Man to an Age of Justice." Toward an Eco-Social Transition: Transatlantic Environmental Humanities / Hacia una Transición Ecosocial: Humanidades ambientales desde una perspectiva transatlántica, ed. M. Isabel Pérez Ramos \& Beatriz Lindo Mañas, Instituto Franklin, forthcoming. CLYMA.

Pérez Ramos, M. Isabel. "The Water Apocalypse: Utopian Desert Venice Cities and Arcologies in Southwestern Dystopian Fiction.” Ecozon@: European Journal of Literature, Culture and Environment 7/2 (2016): 44-64.

Rodríguez, Ralph E. Brown Gumshoes: Detective Fiction and the Search for Chicanalo Identity. U of Texas P, 2005. 55-77.

Romo, Ito. El Puente/The Bridge. U of New Mexico P, 2000.

Ross, Andrew. Bird of Fire: Lessons from the World's Least Sustainable City. Oxford UP, 2011. 
Simmel, Georg. “The Quantitative Aspect of the Group.” The Sociology of Georg Simmel, ed. Kurt Wolff, The Free Press, 1964. 87-174.

Simmel, Georg. "The Stranger." The Sociology of Georg Simmel, ed. Kurt Wolff, The Free Press, 1964. 402-408.

Smith, James A., and Jenni Judd. 'COVID-19: Vulnerability and the power of privilege in a pandemic.' Health Promotion Journal of Australia 31 (2020): 158-60. doi: 10.1002/hpja.333.

Sтевцук, Cathy. “Corpi, Murakami, and Contemporary Hardboiled Fiction.” CLCWeb: Comparative Literature and Culture 5/2 (2003): n.p. Purdue UP. doi: 10.7771/1481-4374.1187.

USMCA. Office of the United States Trade Representative, https://ustr.gov/usmca.

Varsanyi, Monica W. "Rescaling the 'Alien,' Rescaling Personhood: Neoliberalism, Immigration and the State." Annals of the Association of American Geographers 98/4 (2008): 877-896.

Viramontes, Helena María. Under the Feet of Jesus. 1995. Plume, 1996.

Ybarra, Priscilla. Writing the Good Life: Mexican American Literature and the Environment. U of Arizona P, 2016. 
